\title{
SOLAR POWERED SMART IRRIGATION SYSTEM
}

\author{
K. Pradeep Kumar ${ }^{1}$; M.M.Pujara ${ }^{2}$; S.Gokul ${ }^{3}$; M.Gomathi ${ }^{4}$; N.Muthukumar ${ }^{5}$ \\ ${ }^{1}$ Professor; ${ }^{2,3,4,5}$ Student \\ 1,2,3,4,5 Department of Agriculture Engineering, Nandha Engineering College, TN, India \\ ${ }^{1}$ pradeepbvn@ gmail.com; ${ }^{2}$ pujaramoorthi@ gmail.com; ${ }^{3}$ gokul.17ag010@ nandhaengg.org; \\ ${ }^{4}$ gomathi4777@gmail.com; ${ }^{5}$ muthukumar.17ag031@ nandhaengg.org \\ DOI: 10.47856/ijaast.2021.v08i3.005
}

\begin{abstract}
:
Sun energy is used in solar irrigation system to operate the pump which supplies water to crops to assist growth. Cost effective solar power can be answer for all our energy needs. The solar charge controller is used to store DC power of solar panels in batteries. This battery is used for water pump automatically. It works on sunlight. It gives solution for Indian farmers due to energy catastrophe.
\end{abstract}

Keywords: Energy catastrophe, solar power, solar collector.

\section{Introduction:}

Solar energy is that the most ample source of energy within the world. Solar power is not only a solution for today's energy catastrophe but also an ecofriendly forms of energy. Solar cell peer group is the systematic approach for using the solar energy. Solar collectors are nowadays meticulously used for running street lights, for powering water heaters and to meet domestic loads. One of the application of this mechanization is used in flooding systems for husbandry. Solar powered flooding system can be a suitable substitute for farmers in the current state of energy catastrophe in India.

The consumption of photovoltaic electricity in a mechanized flooding system. The tentative setup consists of the controller, control valves, photovoltaic (PV) panels, back up batteries, and sensors. The system is proficient of flooding the fields at a pre-specified time, day/s of the week, and duration. It can also routinely irrigate the field if the soil is dry out below a certain required value. This type of mechanized system will optimize the quantity of water required for a specified crop and area. This system will also help in saving water, besides its other gains ${ }^{[1]}$.

BJT based soil moisture sensor which can be implemented in a large irrigation field. Soil conductivity depends on the moisture content around the probes. A microcontroller is used to scan 


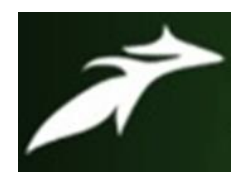

K. Pradeep Kumar et al, International Journal of Advances in Agricultural Science and Technology, Vol.8 Issue.3, March-2021, pg. 48-56

ISSN: 2348-1358

Impact Factor: 6.057

NAAS Rating: 3.77

the array of sensors for output values by operating a switch IC. This paper also shows the results of the experimental conducted using this sensor to highlights the impact of the potash and urea fertilizer on the soil properties ${ }^{[2]}$. a field monitoring and controlling system that is capable of real time and authentic measurement of field statistics. The system is composed of distributed sensing devices such as temperature sensor, moisture sensor and pressure sensor. Sensing unit has sensors and analog to digital converter (ADC) to convert analog sensed signal to digital data. This digital data is processed by the micro controller unit. From here the data is sent to the GPRS (General Packet Radio Service) module and uploaded to the server from which farmer can access the data from anywhere in the world. The information is also sent to LCD module ${ }^{[3]}$.

The automated drip irrigation system irrigation system uses valves to turn irrigation On and OFF. The intend of this paper is to furnish more facility in agriculture field by using wireless sensors network along with linear programming it describes an application of low-cost wireless controlled and monitored irrigation solution ${ }^{[4]}$. The advanced system consists of sensors placed in the farm area, a control station and a base station. Wireless sensor network (WSN) uses ad-hoc networks which support flexibility and self-configuration which is favourable for agricultural application. Data acquired from different sensors is provided to the base station by wireless transmission using zigbee. Once the data are received at the base station, further data processing and computation requirements for decision making are carried out by using data mining algorithm. When real time data is delivered, farmers are able to achieve self regulating crop irrigation system. Hence such enhanced automation for irrigation provides a good electric \& water conservation with more efficiency ${ }^{[5]}$.

Solar energy is the amplest source of energy in the world. Solar power is not only the solution for today's energy catastrophe but also an environmental friendly form of energy. According to the survey directed by the bureau of electrical energy in India in 2011 there are around 18 million agricultural pump sets and around 0.5 million new connections per year is mounted with average capacity 5HP.Total annual consumption in agriculture sector is 131.96 billion kwh (19\% of total electricity consumption). Since PWM technique has been used for inverter operation for minimum harmonics as given in paper which further increases the efficiency of the system. In this system they utilize a soil moisture sensor that detects the amount of moisture appear in the soil and depending upon the condition of level of moisture content ${ }^{[6]}$. 


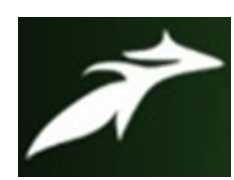

K. Pradeep Kumar et al, International Journal of Advances in Agricultural Science and Technology, Vol.8 Issue.3, March-2021, pg. 48-56

ISSN: 2348-1358

Impact Factor: 6.057

NAAS Rating: 3.77

The main objectives of this solar powered smart irrigation system are to reduce man power for irrigation. To minimize the water use, according to crop requirement. The automatic irrigation can be used for save time and low power monitor device. To reduce labour cost. There is a need to build up some instrument which would work acceptable and must be affordable.

\section{Materials and Methods:}

\section{Solar Panel:}

Solar panels are created with solar cells collected of semiconductor materials. The main function of solar array is to convert solar power into DC electricity (generally of $12 \mathrm{~V})$.

The number of cells and its size depends on the rating of the load for the irrigation.

\section{Charge controller:}

In any solar-power system, a charge controller is an important device, wont to maintain correct charging voltages of the batteries. The charge controller function is to regulate the voltage and current from the solar array.

\section{Temperature \& Humidity Sensor:}

It is used to measure the temperature and humidity present in the irrigation field. It senses and transform message to the field farmer.

\section{Moisture Sensor:}

A moisture sensor is employed to sense the extent of moisture content present within the irrigation field. It's a level detection module during which we set a reference value. It is used to measure the soil moisture.

\section{Battery:}

The Battery is an electrical device, wont to store solar power and supplied to the equivalent loads. The utilization of batteries depends on the load requirement. 


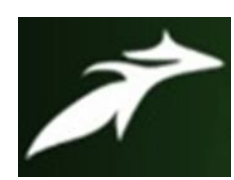

K. Pradeep Kumar et al, International Journal of Advances in Agricultural Science and Technology, Vol.8 Issue.3, March-2021, pg. 48-56

ISSN: 2348-1358

Impact Factor: 6.057

NAAS Rating: 3.77

6. Arduino UNO:

Smart irrigation system using solar energy which drives water pumps to pump water from bore well to a tank and therefore the outlet valve of tank is automatically regulated using Arduino UNO.

\subsection{Specification for designed system:}

\begin{tabular}{|c|c|c|}
\hline S. No & Components & Specifications \\
\hline 1 & Solar panel & $12 \mathrm{~W}$ \\
\hline 2 & Water pump & Small field (0.4) \\
\hline 3 & Size of plants land & $5 \mathrm{~V}$ \\
\hline 4 & Arduino & Sim card required \\
\hline 5 & GSM SIM shield for Arduino & 1 \\
\hline 6 & Soil Moisture Sensor & 1 \\
\hline 7 & Humidity Sensor & 1 \\
\hline 8 & Temperature Sensor & \\
\hline
\end{tabular}

\subsection{Design parameters:}

\begin{tabular}{|c|c|}
\hline Parameters (approx.) & Values \\
\hline Temperature $\left({ }^{\circ} \mathrm{C}\right)$ & 30 \\
\hline Humidity $(\%)$ & 52 \\
\hline Soil Moisture $(\%)$ & 30 \\
\hline
\end{tabular}

\section{Experimental Procedure:}

Solar powered smart irrigation system is concept of using solar panel and automated. In starting of the process, it checks the soil moisture, humidity and temperature. When the level goes low it intimates to switch on the motor. When it reaches the level, it is programmed to turn off the motor. In this system, GSM Module is used to send messages adequately. The power supply depends on two ways. One is through grid and another one is through solar panel. If the supply from the grid system cuts off, automatically it trips to the solar power system. Our product is newly designed by 


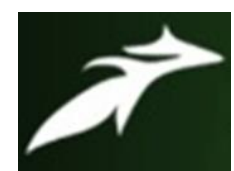

K. Pradeep Kumar et al, International Journal of Advances in Agricultural Science and Technology, Vol.8 Issue.3, March-2021, pg. 48-56

ISSN: 2348-1358

Impact Factor: 6.057

NAAS Rating: 3.77

combining Artificial Intelligence and solar panel. It is unique by combining by solar panel and Artificial Intelligence automation.

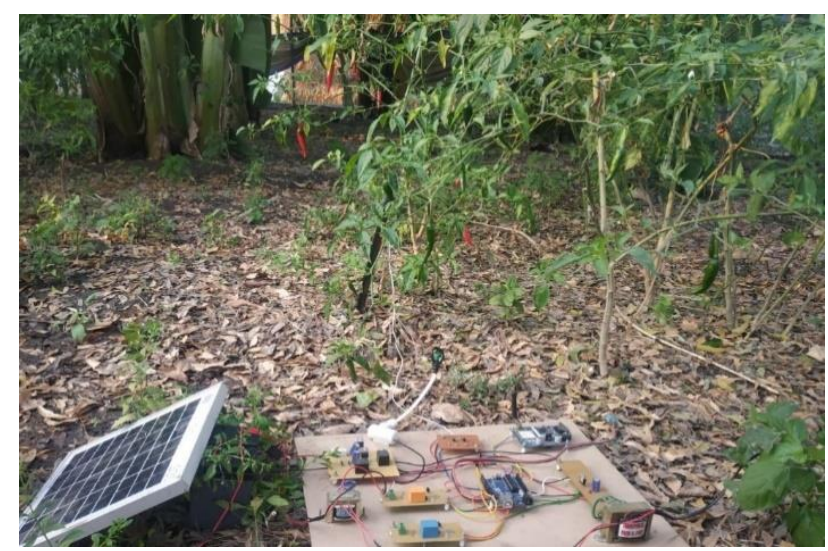

Solar Powered Smart Irrigation System

\section{Result and Discussion:}

By implementing our project is useful for farmers, where we can use both power and solar panel according to the necessity. By developing this kind of irrigation it helps for small and large scale farmers with less effort and with less time. The solar powered smart irrigation system using IoT demonstrates a set of knowledge using sensors for productivity and efficiency.

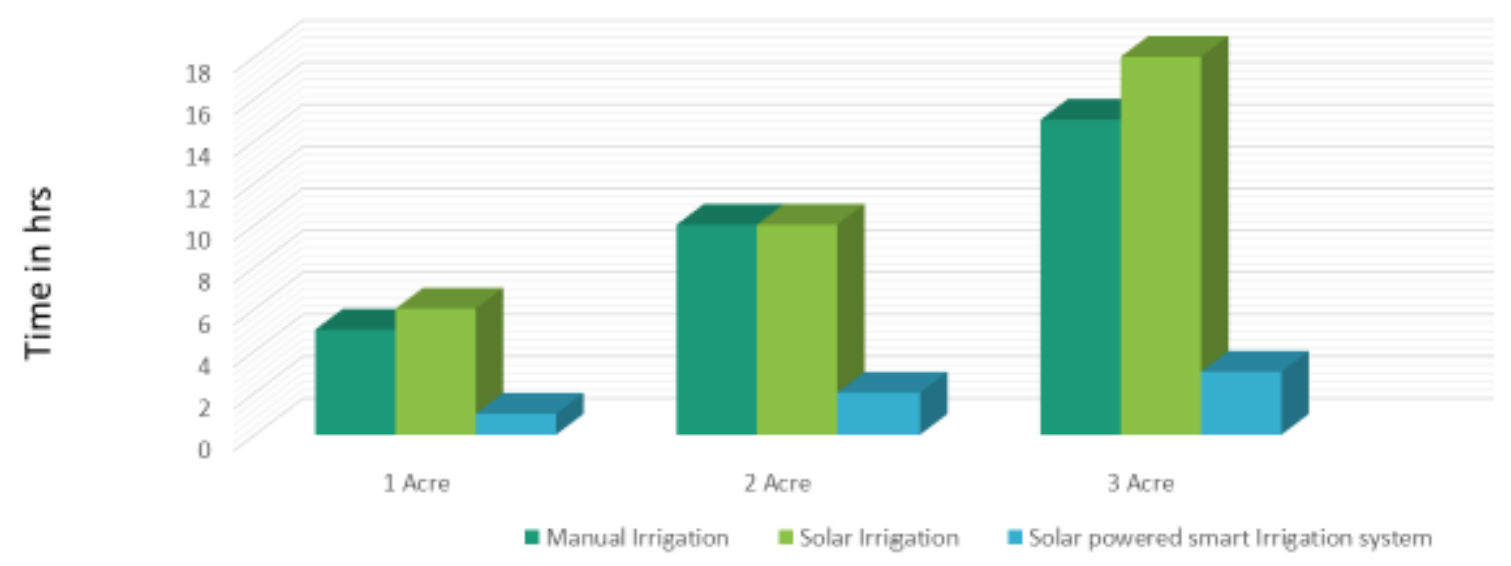

Graph 1. Time vs Area

Compared to manual and solar irrigation, solar powered smart irrigation consumes less time. 


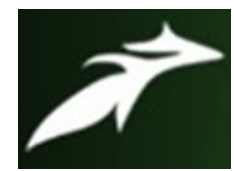

K. Pradeep Kumar et al, International Journal of Advances in Agricultural Science and Technology, Vol.8 Issue.3, March-2021, pg. 48-56

ISSN: 2348-1358

Impact Factor: 6.057

NAAS Rating: 3.77

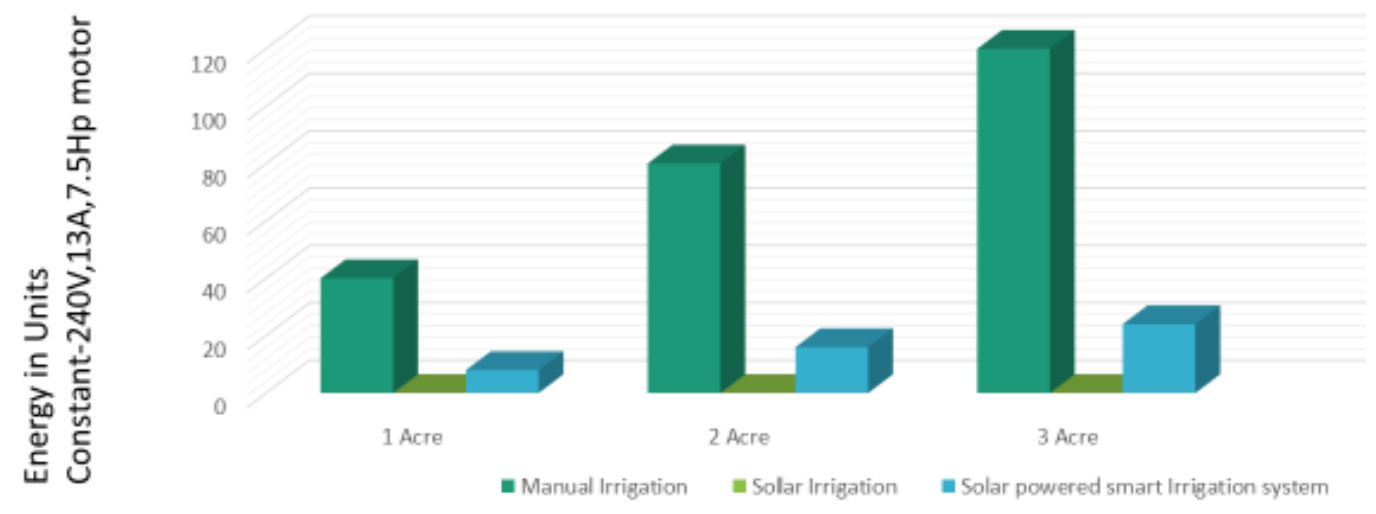

Graph 2. Energy Vs Area

Compared to manual, solar powered smart irrigation consumes less energy while working in Electricity.

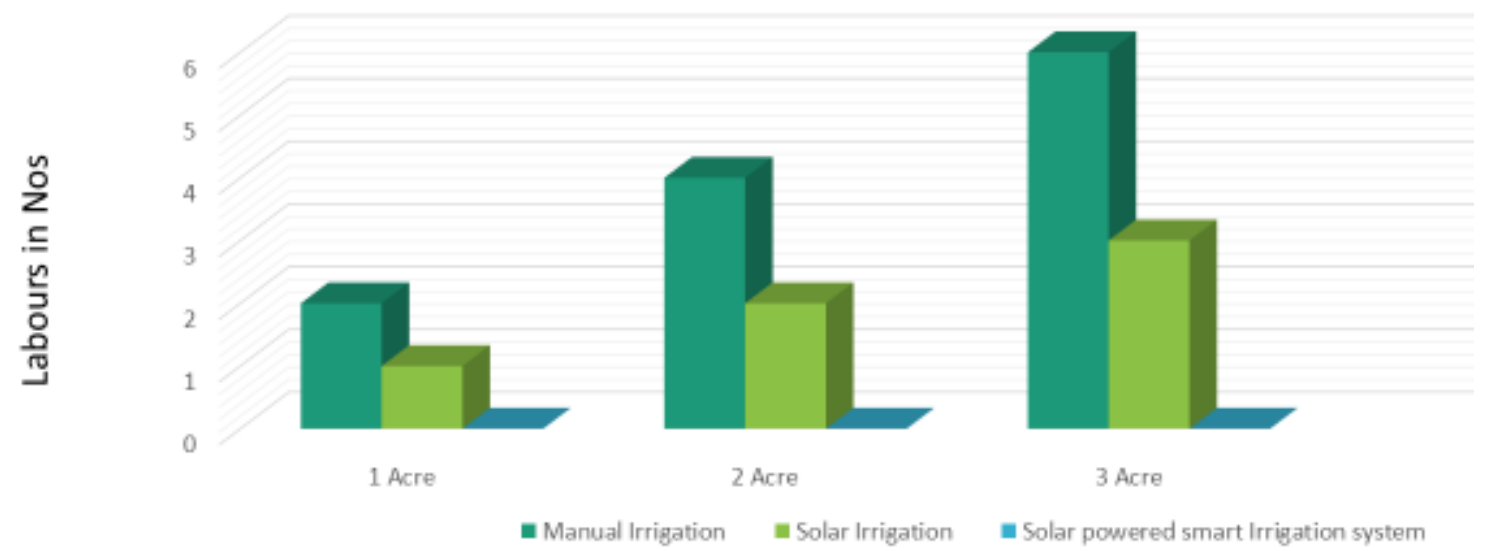

Graph 3. Labour Vs Area

Compared to manual and solar irrigation, solar powered smart irrigation needs no labours while Irrigation. 


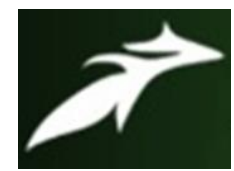

K. Pradeep Kumar et al, International Journal of Advances in Agricultural Science and Technology, Vol.8 Issue.3, March-2021, pg. 48-56

ISSN: 2348-1358

Impact Factor: 6.057

NAAS Rating: 3.77

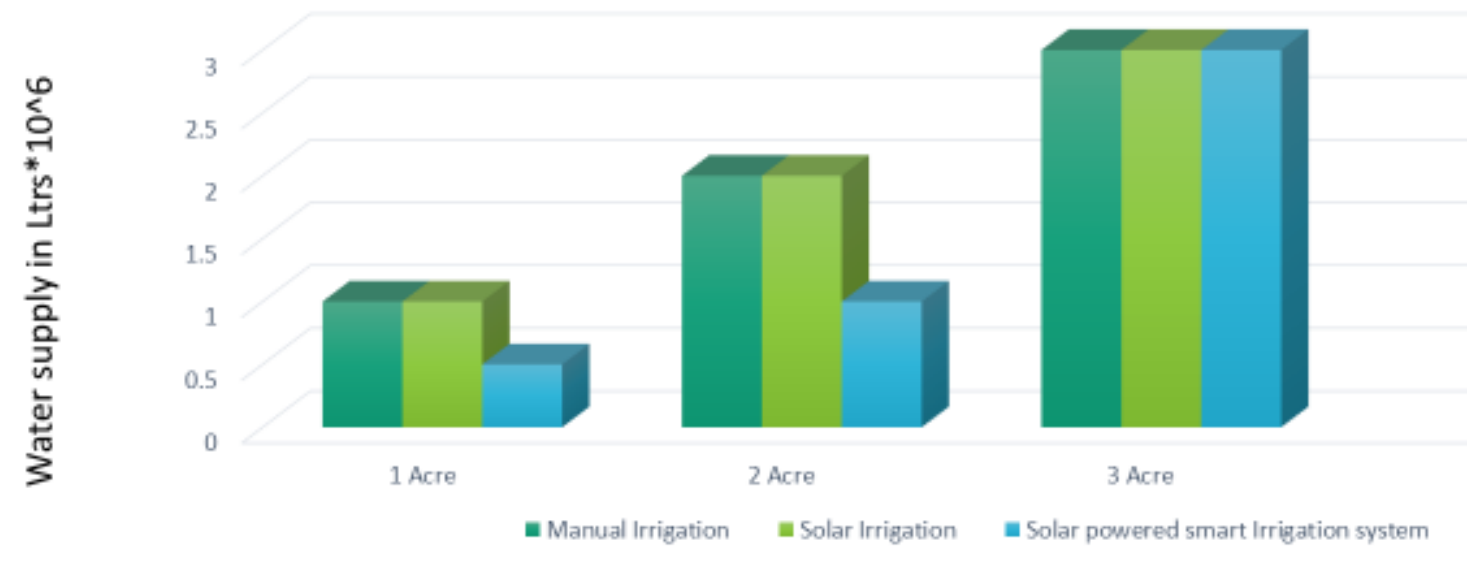

Graph 4. Water supply Vs Area

Compared to manual and solar irrigation, solar powered smart irrigation consumes less water supply according to necessity.

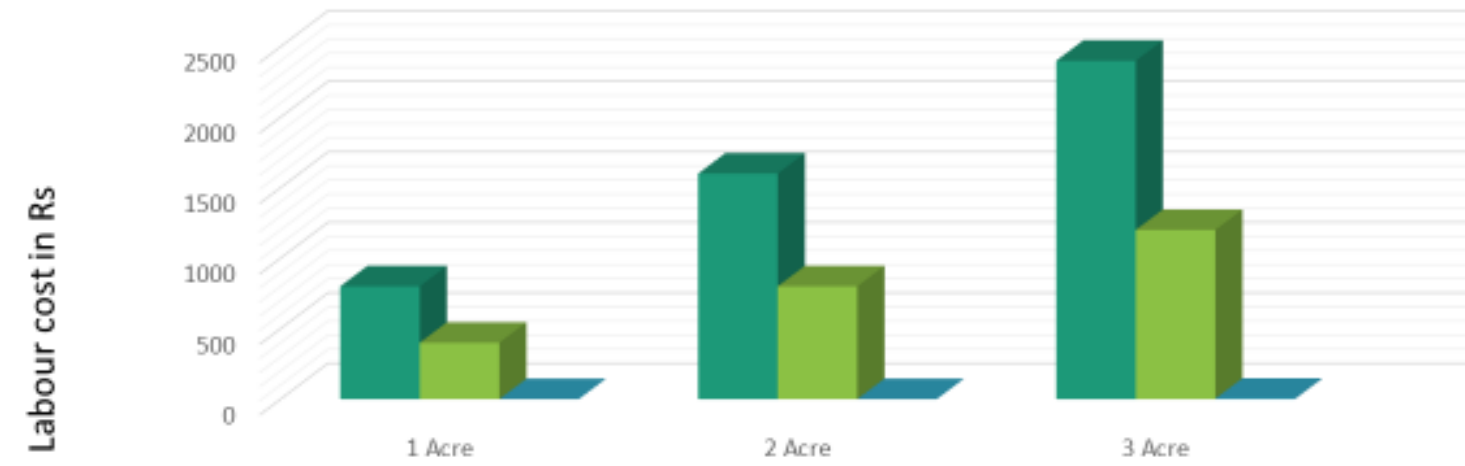

- Manual Irrigation = Solar Irrigation $\quad$ Solar powered smart Irrigation system

Graph 5. Labour Cost Vs Area

Compared to manual and solar irrigation, solar powered smart irrigation needs no labour cost. 


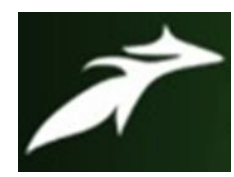

K. Pradeep Kumar et al, International Journal of Advances in Agricultural Science and Technology, Vol.8 Issue.3, March-2021, pg. 48-56

ISSN: 2348-1358

Impact Factor: 6.057

NAAS Rating: 3.77

\section{Comparison on Manual, Solar and Solar Powered Smart Irrigation System:}

\begin{tabular}{|c|c|c|c|}
\hline Comparison & Manual Irrigation & Solar Irrigation & $\begin{array}{c}\text { Solar Powered } \\
\text { Smart Irrigation } \\
\text { system }\end{array}$ \\
\hline Labour & $\begin{array}{l}\text { Depends upon } 2 \\
\text { labours for } 1 \text { acre }\end{array}$ & $\begin{array}{l}\text { Depends upon } 1 \\
\text { labour for a acre }\end{array}$ & $\begin{array}{l}\text { Labour free(online } \\
\text { monitoring) }\end{array}$ \\
\hline Maintenance & $\begin{array}{l}\text { Weekly maintenance } \\
\text { for motor, energy } \\
\text { meter, wire }\end{array}$ & $\begin{array}{l}\text { Virtually no } \\
\text { maintenance as solar } \\
\text { panels(30 years) }\end{array}$ & $\begin{array}{l}\text { Maintenance for } \\
\text { electricity }\end{array}$ \\
\hline Instalment & $\begin{array}{l}\text { Cannot be installed } \\
\text { anywhere }\end{array}$ & $\begin{array}{l}\text { Installed virtually } \\
\text { anywhere }\end{array}$ & $\begin{array}{l}\text { Installed anywhere for } \\
\text { irrigating the crop }\end{array}$ \\
\hline Safety & $\begin{array}{l}\text { Not safer while } \\
\text { accident (leakage of } \\
\text { electric current) }\end{array}$ & $\begin{array}{l}\text { Safer than traditional } \\
\text { irrigation by electric } \\
\text { current }\end{array}$ & Safer \\
\hline Efficiency & Efficiency is good & $\begin{array}{l}\text { Efficiency is } \\
\text { improving so same } \\
\text { size solar is efficient } \\
\text { tomorrow }\end{array}$ & $\begin{array}{l}\text { Combination of both } \\
\text { electricity and solar } \\
\text { panel, so it is more } \\
\text { efficient }\end{array}$ \\
\hline Cost & Initial cost is low & $\begin{array}{l}\text { Initial cost high for } \\
\text { materials and } \\
\text { installation }\end{array}$ & High installation cost \\
\hline Climate & $\begin{array}{l}\text { Doesn't depend on } \\
\text { climate (No irrigation } \\
\text { needed for rainy days) }\end{array}$ & $\begin{array}{l}\text { Cloudy days does not } \\
\text { produce more energy }\end{array}$ & $\begin{array}{l}\text { In cloudy days, } \\
\text { electricity is used for } \\
\text { irrigation purpose }\end{array}$ \\
\hline Production & $\begin{array}{l}\text { Same production } \\
\text { throughout the year }\end{array}$ & $\begin{array}{l}\text { Winter months have } \\
\text { lower production }\end{array}$ & $\begin{array}{l}\text { High production } \\
\text { throughout the year }\end{array}$ \\
\hline
\end{tabular}




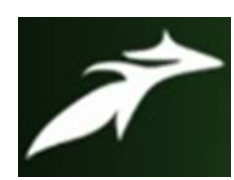

K. Pradeep Kumar et al, International Journal of Advances in Agricultural Science and Technology, Vol.8 Issue.3, March-2021, pg. 48-56

ISSN: 2348-1358

Impact Factor: 6.057

NAAS Rating: $\mathbf{3 . 7 7}$

\section{Conclusion:}

From this review the following conclusions are made,

By implementing our project is useful for farmers, where we can use both power and solar panel according to the necessity. By developing this kind of irrigation, it helps for small- and large-scale farmers with less effort and with less time. This kind of irrigation process consuming a smaller number of labours. By using the automatic irrigation system, it optimizes the usage of water by reducing wastage. Proposed system is easy to implement and environment friendly solution for irrigation fields.

\section{References}

[1] A.R.Al-alia, S.Rehman, S.Al-agilia, M.H.Al-omaria, M.Al-fayezia ," IOT -Solar energy powered smart farm irrigation system", Department of Computer Science Engineering, American University of Sharjah, 26666,United Arab Emirates, vol 23, Aug 2001.

[2] Sanyam Agarwal, Arvind Gautam, Pankaj Singh and Rohit Sharma," A BJT Based Soil Moisture Sensor for Irrigation Monitoring", Bansal Institute of Engineering \&Technology, Meerut SD College of Engineering \&Technology Muzaffarnagar, SRM University, Ghaziabad, vol 2, Jan 2012.

[3] K. Chenna Kesava Reddy, P Venkatrao, "Real Time Field Monitoring and Controlling System", DRK College of engineering and technology, Andhra Pradesh, India, Volume-2, Issue-4, September 2013.

[4] Manish Giri, Department of Computer Engineering MIT Academy of Engineering Alandi(D), University of Pune. Dnyaneshwar Natha Wavhal. Department of Computer Engineering MIT Academy of Engineering Alandi(D), University of Pune," Automated intelligent wireless drip irrigate on using linear programming", Volume 2, Issue 1, January 2013.

[5] Ms. Jyotsna Raut Department of Electronics \& Telecommunication Zeal Education Society's, Prof. V. B. Shere Department of Electronics \& Telecommunication Zeal Education Society's DCOER Narhe, Pune, India DCOER Narhe, Pune, India, Volume 5, Issue (4) July, Technovision-2014, ISSN 2249-071X.

[6] S. Harishankar1, R. Sathish Kumar2, Sudharsan K.P, U. Vignesh and T.Viveknath Department of Electrical and Electronics Engineering, Amrita University Ettimadai, Coimbatore, India," Solar Powered Smart Irrigation System", ISSN 2231-1297, Volume 4, Number 4 (2014), pp. 341-346. 